\title{
基于“互联网 +”的高职航空物流专业教学改革研究
}

\section{Research on the Teaching Reform of Aviation Logistics Major in Higher Vocational Education}

\author{
Based on "Internet +"
}

\section{张雅 王金奉查 李林}

Ya Zhang Xinchun Wang Lin Li

\section{重庆航天职业技术学院}

中国・重庆 400021

Chongqing Aerospace Polytechnic,

Chongqing, 400021, China

基金项目: 重庆市高等教育学会高等教 学科学研究课题,课程编号:CQGJ19B141; 基于“互联网+”的高职航空物流专业教 学改革研究; 中国物流学会教改教研课 题, 课程编号:JZW2019102; 基于“翻转 课堂” 的高职航空物流专业课程教改模 式研究。
【摘要】论文借助“互联网 + ”的技术思维和手段, 研究高职航空物流专业的教学改革, 通 过对人才培养方案、教学条件、教学模式、教学设计的详细研究, 搭建适合于高职航空物流 专业学生需求、符合行业要求的教学模式和方法。

【Abstract】With the help of the technology thinking and methods of "Internet +", this article studies the teaching reform of higher vocational aviation logistics majors. Through the detailed research on talent training programs, teaching conditions, teaching modes, and teaching design, the teaching mode and methods suitable for the needs of students majoring in aviation logistics in higher vocational colleges and in line with the industry requirements are set up.

【关键词】互联网 + ; 高职航空物流; 教学改革

【Keywords \Internet+; higher vocational aviation logistics; teaching reform (DOI) 10.36012/sde.v2i2.1255

\section{1 前言}

中国对物流行业的定位是基础性、战略性的产业, 支撑着 中国国民经济的发展。物流行业发展的难题归根结底就是人 才，因此高职物流专业人才定位和人才培养模式的创新必须 与及行业需求进行密切结合。

\section{2 高职航空物流专业教学现状}

为了向社会提供专业的技术人才,符合 “职教二十条”提 出的“产教融合校企双元育人”的理念, 各大高职院校进行了 一系列的改革, 例如使用 MOOC、翻转课堂、微课等新颖的教 学方法 ${ }^{[1]}$ 。中国开设航空物流专业的高职院校较少, 通过调研 发现, 航空物流专业教学中存在的问题有:一是航空物流专业 课程改革研究较少, 主要集中在某一门课程;二是教学方式单 一, 通过调研发现重庆地区航空物流专业运用 “互联网+教 育”的方式还较少, 需要进一步研究。

\section{3 高职航空物流专业教学改革研究意义}

\section{1 能够提高学生的学习主动性}

基于“互联网+”的高职航空物流专业课程课堂教学更注 重了学生的能动性,学生的课业时间可以自主安排, 利用各类 网络资源进行学习,主动探索知识和技能。在课堂之中, 教师
能够针对学生不理解的地方,进行详细的讲解和指导, 并有针 对性地布置课后作业。

\section{2 教师学生互相促进,教学相长}

基于“互联网+”的高职航空物流专业课程课堂教学更加 注重学生的个性化发展,学生主动探索的能力得到提高、视野 得到扩展、综合素养得到增强。同时,教师的教学和学习能力 也得到提高, 课前需要录制相关教学视频, 课中需要利用各种 手段提高学生的能动性,课后需要设计过程性操作案例。

\section{3 推广现代教育教学技术}

该教学模式需要更多的信息技术来支撑,因此构建一个基 于 “互联网+“的智慧教学平台是极为重要, 这也极大程度的 推广了现代教育教学技术的发展。

\section{4 高职航空物流专业教学改革应用研究}

\section{1 基于互联网 + 高职航空物流专业人才培养}

\section{方案研究}

高职物流专业人才的定位和人才培养模式的创新必须与 新的经济发展以及行业需求进行密切结合，因此在实施基于 “互联网+”的教学模式之前, 需要研究“工学结合、校企合作” 的人才培养模式,对企业以及学生进行调研分析, 并在此基础 上制定相应的人才培养方案,将“互联网+“技术手段运用其 中,根据企业和学生的需求来搭建教学课堂, 这也是教改能够 
理论实践 Theoretical Practice

成功实施的关键。

\section{2 基于“互联网 + ”的教学条件优化研究}

针对目前高职学生在校学习知识时很难将知识转化成为 实操能力的情况,与校企合作单位共建实训基地,采用“网络 学习+课堂讲授+模拟训练+现场操作”的方式进行教学。实训 基地对学校和企业都是双赢的局面, 它不仅能够为本校的学 生提供实操帮助,也可以为企业新招聘人员提供岗前培训。

与企业专业深度合作,由于企业专家因工作原因, 不能给学 生进行现场指导时,则可以利用互联网手段, 录制视频教学, 进 行网络答疑,或者学生在演练的时候企业专家进行远程视频。

\section{3 基于“互联网 +”的教学模式研究}

互联网+时代背景下,物流行业与时俱进,物流人才的培 养也需紧跟时代的步伐, 旧的物流类课堂教学模式需要改进, 可以使用“有效课堂” “翻转课堂” 等新的教学模式, 将此种模 式和“基于工作过程”的教育模式运用到航空物流专业教学设
计当中, 目的在于培育“互联网+”时代下高端技能型新型物 流人才的需求。

\section{4 基于“互联网 +”的教学设计研究}

为了提高航空物流专业学生对系统专业课程的兴趣和学 习的主动性, 课题成员主要从航空物流专业课程标准、教案、 ppt 以及在线课程出发进行专业课程的教学设计。同时, 在课 堂教学中还可以利用在线开放课程平台、学习通、QQ 群等平 台进行互动操作。

\section{5 结语}

“互联网+“是目前职业教育的时代趋势, 因此积极迎合互 联网时代带来的新要求, 深化职业改革的内涵, 从而培养更多 符合航空物流行业发展需求的新人才。

\section{参考文献}

[1]方圆.“互联网 +“时代翻转课堂教学模式研究[J].现代商贸工 业,2016(25):153-154.

\section{（上接第 118 页）}

识到文化知识的重要性,增加学习的积极性,引导老百姓和儿 童参与到文化扶贫这项工作中来，对于乡村减贫事业有着至 关重要的作用,才能让扶贫的工作更有意义。

\section{3 基层文化人才队伍亟待增强}

贫困地区基层公共文化机构的专任工作人员十分缺乏， 严重限制了公共文化服务质量的提高。尤其是部分乡村文化 工作站的工作人员的综合素质不高, 再加上较差的工作和生 活条件, 导致了他们消极的工作态度, 部分工作人在还存在身 兼数职的情况。

\section{3 文化扶贫的对策}

\section{1 加大文化扶贫的宣传力度}

精准扶贫工作，不仅是经济扶贫，也是文化扶贫，但两 者均不是立竿见影的工作, 尤其是文化扶贫。文化扶贫的 首要工作是让老百姓从心里认识到文化的重要意义, 然后 自觉地参与到文化扶贫的工作中, 不仅成为文化脱贫的受 益者, 也是文化脱贫的建设者。高校应该充分利用知识资 源优势, 组织宣传小组, 通过向老百姓传播和讲授精准扶 贫的重要意义, 提高老百姓的参与热情, 并进一步传播文 化知识。

\section{2 高校图书馆在文化扶贫中的重要作用} 高校图书馆肩负着文化育人和服务育人的社会责任。在
目前坚定打赢脱贫攻坚战的背景下，高校图书馆要发挥资源 支持和特色服务双重保障的优势。首先, 高校图书馆可以通过 送书、送剧下乡这样最直接的方式进行文化扶贫。其次, 也可 开展图书借阅服务, 主要针对扶贫地区的留守儿童, 让他们在 乡村也能尽情地在知识的海洋里䢟游。同时, 高校图书馆也可 以通过与扶贫地区的政府的文化部门的合作, 参与到当地的公 共文化服务中去, 提供一定的服务支持。

\section{3 知识小课堂}

儿童是祖国的未来, 因此, 文化扶贫的工作重心之一即儿 童。通过每周为儿童举办一次知识小课堂的方式, 丰富儿童的 课外生活。知识小课堂的内容可以丰富多彩, 如举办诗朗诵比 赛、手工制作、音乐欣赏等, 使儿童的知识体系更加宽阔, 而不 仅仅局限在学校的书本知识中。

\section{4 结语}

文化扶贫的目的是用最少的钱,收获最大的效果, 投入产 出比较高。“治贫”必先“治愚”, 努力发展农村的文化事业, 提 高农民的思想文化素质和生产科学技术水平, 是促进农村经 济发展, 从根本上改善农民生活的关键所在。

\section{参考文献}

[1]郭晓君.文化贫困: 内涵与界定 $[\mathrm{J}]$.西华师范大学学报:哲学社 会科学版,2005(2): 1 .

[2]李楠,间韶华.文化扶贫及其实践路径分析 [J].兵团党校学报, 2018(3):105-108. 